\title{
A RAPID AND PRECISE METHOD FOR THE DETERMINATION OF UREA
}

\author{
BY \\ J. K. FAWCETT AND J. E. SCOTT* \\ From the Surgical Unit, St. Mary's Hospital, London
}

(RECEIVED FOR PUBLICATION SEPTEMBER 28, 1959)

\begin{abstract}
A method is described for the determination of urea in plasma and urine. The effects of variations in the experimental conditions are examined and the results of recovery experiments and other tests of precision and accuracy are reported.

In comparison with other methods in current use, this method has distinct advantages in sensitivity, simplicity, and precision, thus economizing in time, sample volume, reagents, and equipment.
\end{abstract}

Although urea in biological fluids is frequently measured, a method has yet to be described which is precise, sensitive, and simple. Those most commonly used depend on the measurement of ammonium carbonate produced by hydrolysis with urease, or on the measurement of the yellow pigment formed by condensing diacetyl with urea. The best results are obtained by urease hydrolysis followed by aeration and titration of ammonia, but this requires large samples and is time consuming.

The reaction of ammonia with sodium phenate and hypochlorite to produce a blue colour (Berthelot, 1859; Thomas, 1912) was used by Borsook (1935) in the estimation of ammonium carbonate produced by hydrolysis of urea. Lubochinsky and Zalta (1954) found that the colour reaction was greatly improved in speed, yield, and reproducibility by the presence of sodium nitroprusside as a catalyst. Their discovery is adapted here for the determination of urea after hydrolysis with urease. The present method is as simple and rapid as techniques using Nessler's reagent or diacetyl, but has greater precision, similar to that of the aeration-titration procedure. It can be applied to as little as $10 \mu \mathrm{l}$. of plasma.

\section{Method}

Reagents.-Some distilled water may contain sufficient ammonia to make it unsuitable for the preparation of reagents and standards and for the dilution of samples. It is therefore necessary to redistil from all-glass apparatus or to use a cation exchange resin, e.g., Zeo-Karb $225, \mathrm{Na}$ form. As an additional safeguard, the same batch of water is used for the preparation of the blanks and dilute standards and for the dilution of the samples.

Stock Urea Standard.-This is $1.071 \mathrm{~g}$. of urea per litre, containing $500 \mathrm{mg}$. of urea nitrogen per litre, and may be checked by Kjeldahl analysis.

Dilute Urea Standards.-Dilutions of the stock standard of $1: 250$ and $1: 100$ containing $2 \mathrm{mg}$. and $5 \mathrm{mg}$. of urea nitrogen per litre.

Buffer.-Monopotassium dihydrogen phosphate, $6 \mathrm{~g}$., and $2 \mathrm{~g}$. of disodium monohydrogen phosphate per litre.

Buffered Urease Solution.-About 200 Sumner units (about $30 \mathrm{mg}$.) of special purity urease ${ }^{1}$ per $100 \mathrm{ml}$. of a $1 \%$ solution of the buffer. This keeps 용 for about a week in a refrigerator. Each day sufficient is removed for immediate requirements and any excess is discarded.

Sodium Phenate. - Phenol, A.R., 25.0 g., is dissolved in about $800 \mathrm{ml}$. of water, mixed with $78 \mathrm{ml}$. of $4.0 \mathrm{~N}$-sodium hydroxide solution, and diluted to 9 1 litre. This keeps for at least a month in a refrigerator but should not be used when it turns brown. It must be brought to room temperature $\bar{N}$ before use.

Sodium Nitroprusside, $1 \%$. -This keeps for at least $\mathcal{N}^{\circ}$ a month in darkness at room temperature.

Sodium Nitroprusside, $0.01 \%$. -A $1: 100$ dilution of the $1 \%$ solution keeps for at least a week in darkness at room temperature.

Sodium Hypochlorite, about $0.02 \quad \mathbf{N}$.-This is $\stackrel{\mathscr{D}}{+}$ prepared by diluting a commercially available stock $\square$ solution $^{2}$ and standardized iodometrically (Vogel, $\bar{o}$

${ }^{1}$ Special purity urease is obtained from Sigma Chemical Co., U.S.A. (U.K. Agents: George T. Gurr Ltd., 136, New King's Road, London, S.W.6.)

${ }^{2}$ Sodium hypochlorite solution, $10-14 \% \mathrm{w} / \mathrm{w}$ available chlorine, is obtained from Hopkin and Williams Ltd., Chadwell Heath, Essex, and from British Drug Houses Ltd., Poole, Dorset. 
1951) by adding excess acid and potassium iodide and titrating with sodium thiosulphate. A variation of $\pm 20 \%$ in normality has no measurable effect on results. This solution keeps for at least a month in darkness at room temperature.

Urease Incubation.-The sample incubated with urease preferably contains between 1 and $5 \mu \mathrm{g}$. of urea nitrogen. Therefore plasma is diluted $1: 100$, or $1: 500$ if the concentration is known to be high, and urine is diluted $1: 1,000$ or $1: 2,500$. One millilitre portions of water, dilute standards, and dilute samples are measured into 6 in. by 1 in. test tubes. One millilitre of buffered urease solution is added to each, which is then placed in a $37^{\circ} \mathrm{C}$. water-bath for five minutes or left at room temperature for 10 minutes.

An alternative procedure is to pipette $10 \mu 1$. portions of stock urea standard and of plasma directly into $2 \mathrm{ml}$. of urease solution and to incubate as above. This avoids prior dilution, but the precision is limited by that of the pipette. Repetitive measurements with a constriction pipette, calibrated to contain $10 \mu \mathrm{l}$., have a coefficient of variation of about $1 \%$.

Preformed Ammonia.-In all methods depending on the quantitative hydrolysis of urea to ammonium carbonate, preformed ammonia contributes to the final measurement. It is customary to neglect plasma ammonia, but if accurate urea results are required on urine the ammonia nitrogen must be allowed for. Urinary ammonia is measured by the same procedure as that described, substituting water for the urease solution; $1 \mathrm{ml}$. of a 1:200 dilution is usually satisfactory.

Colour Development. - After incubation, the following solutions are added immediately after each other to each tube: $2 \mathrm{ml}$. of sodium phenate, $3 \mathrm{ml}$. of $0.01 \%$ sodium nitroprusside, and $3 \mathrm{ml}$. of sodium hypochlorite. Maximum colour development is greatest in the absence of direct sunlight and is complete in 15 minutes at $27^{\circ} \mathrm{C}$. and 30 minutes at $19^{\circ} \mathrm{C}$. Optical density at $630 \mathrm{~m} \mu$ is then constant for at least 24 hours.

After subtraction of blank readings, optical density is directly proportional to urea concentration.

\section{Results}

The results presented here describe $(a)$ the characteristics of the reaction, including the effect of variations in the experimental conditions; and (b) the precision and accuracy of the method, as measured by replicate analysis, recovery experiments, comparison with results by the aerationtitration technique, and tests for interference by other substances.

Characteristics of the Reaction.-The interaction of ammonia, phenate, and hypochlorite yields an absorption curve which is reported to have a maximum near $625 \mathrm{~m} \mu$. The exact position of this maximum depends upon such factors as the concentration of reagents and the presence of catalysts. With the present method, and a "unicam SP500" spectrophotometer, we found the maximum at $630 \mathrm{~m} \mu$. Ilford spectrum orange filters 607 , in a Hilger Spekker absorptiometer, gave satisfactory results.

The relationship between concentration and optical density is linear. If the sample after incubation contains more than $6 \mu \mathrm{g}$. of ammonia nitrogen, the coloured solution may be diluted in water and measured against the similarly diluted blank. This is valid even in the presence of $30 \mu \mathrm{g}$. of ammonia nitrogen, which would be produced from a 1:100 dilution of plasma containing $300 \mathrm{mg}$. of urea nitrogen per $100 \mathrm{ml}$.

It is important that the colour reagents are added promptly after each other. For every minute interval between the addition of nitroprusside and hypochlorite the final optical density is diminished by about $1.5 \%$.

The depression of optical density by direct sunlight may be of the order of $10 \%$, but filament and strip lighting are without effect. Although precautions can be taken to subject standards and unknowns to equal sunlight, it is better to carry out the reaction where natural lighting is minimal or to develop the colour in darkness.

Temperature has important effects on the speed and intensity of colour development. Maximum optical density is attained in 30 minutes at $19^{\circ} \mathrm{C}$., 20 minutes at $24^{\circ} \mathrm{C}$., 15 minutes at $27^{\circ} \mathrm{C}$., and five minutes in a $37^{\circ} \mathrm{C}$. water-bath. In each case the density is then stable for at least 24 hours. Development in a $37^{\circ} \mathrm{C}$. water-bath yields densities about $10 \%$ less than development at $20^{\circ} \mathrm{C}$., standards and unknowns being influenced equally, provided that the interval between adding the reagents and transferring to the bath is constant. It is more convenient to develop colour at room temperature, except in emergency work when each tube is placed in the $37^{\circ} \mathrm{C}$. bath immediately after adding the reagents and is left there for five minutes.

The phenate-hypochlorite reaction is influenced by $p \mathrm{H}$, and it was necessary to incorporate buffers in applying it to Kjeldahl digests (Lubochinsky and Zalta, 1954) or to acid solutions for absorption of ammonia (Brown, Duda, Korkes, and Handler, 1957). In the present application the inclusion of a buffer has proved unnecessary.

It was not found possible to simplify the procedure by combining colour reagents, as the combinations are very unstable. The effect of decreasing the concentration of either sodium phenate or nitroprusside is to retard colour 
development; the effect of an increase is to intensify the reagent blank. The ratio of sodium hydroxide to phenol is optimum for rapid colour formation. A variation of $\pm 20 \%$ in the iodometric titre of fresh $0.02 \mathrm{~N}$-hypochlorite solution has no effect on the speed and intensity of colour development. After about two weeks the solution may deteriorate, resulting in delayed colour development. This deterioration is not accompanied by a parallel change in iodometric titre.

Precision and Accuracy.-In assessing the precision and accuracy of this method, it has been compared with the urease-aeration-titration procedure, which we considered the most reliable. Standard urea solutions were included in each aeration series and the acid titres required by the unknowns were related to those required by the standards. For the purpose of comparison, urine ammonia concentrations were not subtracted in either method.

Table I compares the precision of the two methods. The errors of the present method were proportional to the urea concentration, while

TABLE I

PRECISION OF UREASE-PHENATE-HYPOCHLORITE AND UREASE-AERATION-TITRATION METHODS

\begin{tabular}{|c|c|c|}
\hline & $\begin{array}{c}\text { Present Method } \\
(\%)\end{array}$ & $\begin{array}{c}\text { Aeration Me thod } \\
(\%)\end{array}$ \\
\hline $\begin{array}{l}\text { Standard urea solutions } \\
\text { Plasma samples containing less } \\
\text { than } 50 \text { mg. urea } \mathrm{N} / 100 \text { ml. } \\
\text { Plasma samples } \\
\text { more than } 50 \\
\text { containing } \\
\text { N/100 ml. } 5 . \\
\text { Urine samples }\end{array}$ & $\begin{array}{l}1.0 * \\
1.2 \\
1.0 \\
1.0\end{array}$ & $\begin{array}{l}0.8 \\
4.0\end{array}$ \\
\hline
\end{tabular}

- Values reported are coefficients of variation $\left(\frac{\text { S.D. }}{\text { Mean }} \times 100\right)$ calcu-

lated in each case from duplicate results on $\mathbf{5 0}$ samples.

those of the aeration procedure were more constant irrespective of the quantity of ammonia produced. Table I thus shows that for normal or slightly raised plasma urea concentrations the orecision was much better by the present method, whereas at higher concentrations the aeration procedure was slightly better.

Table II compares the results obtained by the two techniques on 18 plasma and 15 urine samples. Agreement was generally good, the most significant discrepancies occurring in plasma samples of low urea concentration, where the aeration procedure was less reliable.

Table III reports the results of recovery experiments on five specimens of plasma and five of urine. Most recoveries were correct within $1 \%$.
Mean recoveries were $100 \%$ by the present metho and $99.3 \%$ by aeration.

The recovery experiments and the goof correlation with the aeration method suggested that there was unlikely to be significant inter $\frac{\text { 을 }}{5}$ ference by substances commonly encountered if plasma or urine. Nevertheless, five substance\& that might interfere were investigated, namelyes glucosamine, glutamine, and citrulline, which readily liberate ammonia, and bilirubin and haemoglobin. Each of these substances wasu added to diluted plasma in concentrations shown: in Table IV. The three labile amines caused nœ interference, and the interference by high concen $\vec{\omega}$ trations of bilirubin was small. Interference biv

TABLE II

COMPARISON OF RESULTS BY THE UREASE-PHENATEHYPOCHLORITE AND UREASE-AERATION-TITRATION METHODS ON 18 SAMPLES OF PLASMA AND 15 SAMPLES OF URINE

\begin{tabular}{c|c|c|c}
\hline $\begin{array}{c}\text { Present } \\
\text { Method }\end{array}$ & $\begin{array}{c}\text { Aeration } \\
\text { Method }\end{array}$ & Difference & $\begin{array}{c}\text { Percentage } \\
\text { Difference } \\
\text { A-B }\end{array}$ \\
(A) & (B) & (A-B) & $\left(\frac{\hat{\sigma}}{\mathbf{A}} \times 100\right.$ g \\
\hline
\end{tabular}

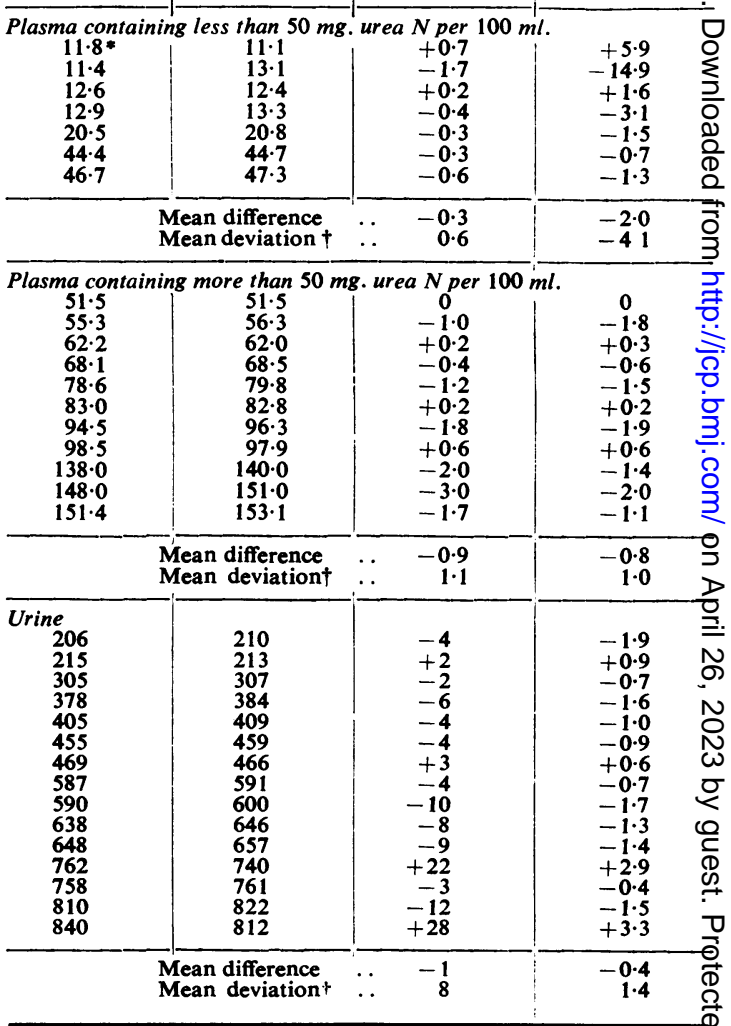

* Values reported are means of duplicate results in $\mathrm{mg}$. of ure? $\mathrm{N}$ per $100 \mathrm{ml}$.

† Disregarding sign. 
TABLE III

RECOVERY OF UREA* BY UREASE-PHENATEHYPOCHLORITE AND UREASE-AERATION-TITRATION METHODS

\begin{tabular}{|c|c|c|}
\hline $\begin{array}{c}\text { Initial } \\
\text { Concentration }\end{array}$ & $\begin{array}{l}\text { Recovery by } \\
\text { Present Method }\end{array}$ & $\begin{array}{c}\text { Recovery by } \\
\text { Aeration Method }\end{array}$ \\
\hline $\begin{array}{r}11 \\
13 \\
21 \\
51 \\
138\end{array}$ & $\begin{array}{l}251 \\
247 \\
251 \\
254 \\
249\end{array}$ & $\begin{array}{l}251 \\
248 \\
251 \\
248 \\
243\end{array}$ \\
\hline $\begin{array}{l}\text { Mean recovery for plasma } \\
\text { Mean deviationt from } \\
250 \mathrm{mg} . / 100 \mathrm{ml} . .\end{array}$ & $\begin{array}{r}250 \\
2\end{array}$ & $\begin{array}{r}248 \\
3\end{array}$ \\
\hline $\begin{array}{l}206 \\
215 \\
378 \\
387 \\
405\end{array}$ & $\begin{array}{l}249 \\
252 \\
253 \\
251 \\
243\end{array}$ & $\begin{array}{l}249 \\
245 \\
251 \\
250 \\
248\end{array}$ \\
\hline $\begin{array}{l}\text { Mean recovery for urine } \\
\text { Mean deviationt from } \\
250 \mathrm{mg} .100 \mathrm{ml} . .\end{array}$ & $\begin{array}{r}250 \\
3\end{array}$ & $\begin{array}{r}249 \\
2\end{array}$ \\
\hline
\end{tabular}

* Urea recovered from five samples of plasma and five samples of urine when urea was added to increase the concentration by $250 \mathrm{mg}$. $\mathrm{N}$ per $100 \mathrm{ml}$. Values reported are means of duplicate results in $\mathrm{mg}$. of urea $\mathrm{N}$ per $100 \mathrm{ml}$.

$\dagger$ Disregarding sign.

TABLE IV

TESTS FOR INTERFERENCE BY GLUCOSAMINE, GLUTAMINE, CITRULLINE, BILIRUBIN, AND HAEMOGLOBIN

\begin{tabular}{|c|c|c|c|c|}
\hline $\begin{array}{c}\text { Added } \\
\text { Substance }\end{array}$ & $\begin{array}{c}\text { Concen- } \\
\text { tration } \\
\text { in Plasma } \\
(\mathrm{mg} . / 100 \mathrm{ml} .)\end{array}$ & $\begin{array}{c}\text { Plasma } \\
\text { Urea N } \\
\text { (mg./100 ml.) }\end{array}$ & $\begin{array}{c}\text { Plasma } \\
\text { Dilution }\end{array}$ & $\begin{array}{c}\text { Apparent } \\
\text { Increase } \\
\text { in Urea N } \\
\text { (mg./100 ml.) }\end{array}$ \\
\hline $\begin{array}{l}\begin{array}{l}\text { Glucos- } \\
\text { amine .. } \\
\text { Glutamine } \\
\text { Citrulline } \\
\text { Bilirubin }\end{array} \\
\begin{array}{c}\text { Haemo- } \\
\text { globin }\end{array}\end{array}$ & $\begin{array}{r}20 \\
20 \\
20 \\
10 \\
25 \\
40 \\
50 \\
75 \\
75 \\
150 \\
150 \\
150 \\
150 \\
200 \\
200 \\
250 \\
300 \\
300 \\
300 \\
600\end{array}$ & $\begin{array}{r}17 \\
92 \\
92 \\
22 \\
151 \\
88 \\
34 \\
65 \\
92 \\
13 \\
17 \\
65 \\
92 \\
65 \\
92 \\
128 \\
13 \\
92 \\
119 \\
119\end{array}$ & $\begin{array}{c}1: 100 \\
1: 100 \\
1: 100 \\
1: 100 \\
1: 500 \\
1: 500 \\
1: 100 \\
1: 500 \\
1: 500 \\
1: 100 \\
1: 100 \\
1: 500 \\
1: 500 \\
1: 500 \\
1: 500 \\
1: 500 \\
1: 100 \\
1: 500 \\
1: 500 \\
1: 500\end{array}$ & $\begin{array}{c}0 \\
0 \\
0 \\
+0.3 \\
+1.5 \\
+0.7 \\
+0.1 \\
-0.4 \\
-0.4 \\
+2.0 \\
+0.5 \\
+0.7 \\
+0.3 \\
+2.1 \\
+1.2 \\
+0.8 \\
+2.7 \\
+1.2 \\
+2.1 \\
-3.0\end{array}$ \\
\hline
\end{tabular}

haemoglobin was greater and unpredictable, being positive at low urea levels and negative at high ones. This indicates that accuracy is reduced in the presence of haemolysis.

All methods employing urease followed by measurement of the products of hydrolysis yield a result with plasma even in the absence of the enzyme. This may be due partly to plasma ammonia, and possibly other substances, and partly to non-enzymic hydrolysis of urea. In a series of 10 plasma samples stored in a refrigerator up to 30 hours and containing from 8 to $140 \mathrm{mg}$. of urea nitrogen per $100 \mathrm{ml}$., this was found to correspond to an average of $0.4 \mathrm{mg}$. of nitrogen per $100 \mathrm{ml}$. by both the new and aeration methods. Three plasma samples which had been stored in a refrigerator for two months gave results of 1.6 to $2.9 \mathrm{mg}$. of nitrogen per $100 \mathrm{ml}$.

\section{Discussion}

The 'great sensitivity of the colour reaction permits the measurement of very small amounts of urea in small samples, which therefore require very little urease. Special purity urease is to be preferred to cruder preparations because of the lower blanks, maximum specificity, and absence of insoluble material which would require centrifuging. Although the special purity enzyme is expensive, so little is used that the cost of reagents with this method is about one-fifth of that using commercial urease tablets and aeration.

The precision of this method is as good as that of the best routine procedure. There is, however, one hazard arising from the sensitivity of the colour reaction, and this is the unintentional use of distilled water containing ammonia, for example, from a wash bottle.

The present method is about as quick as the Nesslerization and diacetyl procedures and is considerably quicker than the aeration technique. This remains true if one takes into account time spent in preparing reagents and cleaning apparatus. In the presence of exceptionally large quantities of urea, it has a great advantage over other methods because one can validly dilute the final solution for absorptiometry instead of having to repeat the assay from the beginning. It is also convenient that, without any special modification, this procedure is equally suitable for plasma, urine, and other biological material.

We thank Dr. Victor Wynn, M.D., for his encouragement and support; and Miss Susan Slade and Mr. Paul Whiteman, who helped with the analyses.

\section{REFERENCES}

Berthelot (1859). Répert. Chim. appl., 1, 284.

Borsook, H. (1935), J. biol. Chem., 110, 481.

Brown, R. H., Duda, G. D., Korkes, S., and Handler, P. (1957). Arch. Biochem. Biophys., 66, 301.

Lubochinsky, B., and Zalta, J. P. (1954). Bull. Soc. Chim. biol., 36, 1363.

Thomas, P. (1912). Bull. Soc. Chim. Fr., ser. 4, 11, 796

Vogel, A. I. (1951). A Text-book of Quantitative Inorganic Analysis, 2nd ed., p. 350. Longmans, Green, London. 